\title{
Foresight of Tourism in Kazakhstan: Experience Economy
}

\author{
Nurzhan Kenzhebekov ${ }^{1,2}$, Yerlan Zhailauov ${ }^{2,3}$, Emil Velinov ${ }^{4,5, *}$, , Yelena Petrenko ${ }^{6}$ (1) and Igor Denisov ${ }^{6,7}$ \\ 1 Department of Tourism and Restaurant Business, Karaganda Economic University of Kazpotrebsoyuz, \\ Karaganda 100009, Kazakhstan; kenzhebekov@mail.ru \\ 2 «Rational Solution» LLP, Karaganda 100009, Kazakhstan; zhailauov@rationalsolution.kz \\ 3 Department of Economics and Entrepreneurship, Karaganda Economic University of Kazpotrebsoyuz, \\ Karaganda 100009, Kazakhstan \\ 4 Department of Management and Marketing, Skoda Auto University, 1457 Na Karmeli, \\ 29301 Mladá Boleslav, Czech Republic \\ 5 Department of Business, RISEBA University of Applied Sciences, LV-1048 Riga, Latvia \\ 6 Academic Department of Management Theory and Business Technologies, Plekhanov Russian University of \\ Economics, Stremyanny Lane 36, 117997 Moscow, Russia; petrenko.es@rea.ru (Y.P.); denisov.iv@rea.ru (I.D.) \\ 7 Department of Public Administration and Personnel Policy, Moscow Metropolitan Governance Yury Luzhkov \\ University, st. Sretenka, 28, 107045 Moscow, Russia \\ * Correspondence: emil.velinov@savs.cz
}

check for updates

Citation: Kenzhebekov, N.; Zhailauov, Y.; Velinov, E.; Petrenko, Y.; Denisov, I. Foresight of Tourism in Kazakhstan: Experience Economy. Information 2021, 12, 138. https:// doi.org/10.3390/info12030138

Academic Editor: Puiu Nistoreanu

Received: 27 February 2021

Accepted: 21 March 2021

Published: 23 March 2021

Publisher's Note: MDPI stays neutral with regard to jurisdictional claims in published maps and institutional affiliations.

Copyright: (c) 2021 by the authors. Licensee MDPI, Basel, Switzerland. This article is an open access article distributed under the terms and conditions of the Creative Commons Attribution (CC BY) license (https:// creativecommons.org/licenses/by/ $4.0 /)$.

\begin{abstract}
The paper sheds a light on the interconnections between touristic sector development and regional development in Kazakhstan. The paper covers analysis of the current competitiveness of the touristic destinations in Kazakhstan. Based on qualitative and quantitative research, the study shows that there is a huge need for a transformation in marketing communications tools in order to increase the competitiveness and image of Kazakhstani tourism. The study provides potential scenarios and solutions to increase touristic attractiveness, which would lead to enticing more investors and increase tourism capacity and potential. Also, the paper provides insights in ecotourism and the regional economy by outlining the older and newer managerial and governmental approaches in supporting the entire tourism sector in Kazakhstan.
\end{abstract}

Keywords: touristic sector; marketing communications; experience economy; Kazakhstan

\section{Introduction}

The relevance of the topic of tourism development as an industry of the national economy of Kazakhstan is conditioned by the country's political management understanding the need to move from a commodity to a diversified economy. The importance of the development of the hospitality industry as one of the priority areas of tourism development in the Republic of Kazakhstan is noted in research [1]. In order to determine the prospects of this policy, periodic analysis of state support measures for the development of tourism in the country is carried out [2] and assessment of the effectiveness of regional tourism policy [3]. In business practice conceptual approaches in the area of sustainable tourism are based on the usage of integrated marketing approaches [4]. Scientists and practitioners define tourism as a stochastic driver for socio-economic and socio-cultural development of a country [5].

In today's environment, tourism as an industry can have a significant impact on the growth of new types of business in the country. Tourism products are not just sold domestically, tourist services are consumed locally, and therefore bring income to the local cultural and business communities that created them [3]. According to expert estimates, one currency invested in tourism leads to 5 units of revenue growth, and although this potential has not yet been realized in Kazakhstan, the multiplier effect is at least three times the accompanying turnover. Thus, determining the ways to develop the tourism industry in the country is not just an urgent task, but perhaps one of the promising areas of development of the national economy [1]. 
The development of the tourism industry in Kazakhstan is in many ways a state task, as it contributes to the formation of local business, the formation of local cultural communities and thus contributes to the diversification of the economy [2]. Geographically, the country includes many tourist attractions based on a combination of unique landscapes and cultural heritage associated with the Great Silk Road, but as a tourist destination it is relatively unknown in both the world and Central Asia [1]. Thus, the search for ways to develop tourism is an urgent task that requires a systematic solution [5].

The interest in the development of touristic sector in Kazakhstan has increased since 2004, when the national economy was on the rise during the sustainable development of and increasing demand and supply for global oil.

The authorities of the country faced a pressing question: how to develop the tourism sector as part of the national economy?

The state's interest was shown in the concept of cluster development [6]. The Government initiated the development of cluster models and strategies aimed at realizing the national economy's advantages. The formation and development of industry clusters was supposed to contribute to the effective integration of intellectual and financial resources both in the regions and throughout the country.

The concept of "industrial clusters" was proposed by M. Porter in 1990 [6]. Michael Porter defined clusters as geographically close groups of interconnected companies, specialized suppliers, service providers, firms in related industries, and related institutions in certain areas that compete but also cooperate [7]. For several decades, cluster policy has become a central element of territorial development decision-making processes. Benefits, especially in terms of collective learning, knowledge sharing and other types of agglomeration economy, as well as related effects, have been noted in the scientific literature on regional development [8,9].

Cluster formation is based on the fact that participants are located in geographical proximity, which is largely positively influenced by external factors that make productivity possible. Positive external effects arise from a agglomeration of knowledge and labour that combines industries, technologies, skills and acquired resources. Although Porter's original work on "competitive advantage" focused mainly on production, it was recognized that these works could also be applied in services such as tourism. Research on the industrial tourist cluster began relatively late, but scientists have made some progress after years of research using a cluster chart and a "Porter diamond model" [10].

At the beginning of the 21st century, it was assumed that tourist clusters could be the best way to objectify the production and supply of tourist products at the level of individual tourist destinations, especially larger in spatial terms.

The authority of the cluster approach was so high that the author of the theory, Professor M. Porter, of Harvard Business School, was invited to develop cluster initiatives in Kazakhstan. With his participation, the National Center for Marketing and Analytical Research launched a project "Assessing the competitiveness of existing and potentially promising sectors of Kazakhstan's economy and making recommendations for their development". The study identified seven pilot industries, including tourism.

However, according to the state statistics in the resort areas of Kazakhstan, only one tourist cluster (Almaty Mountain) was formed, providing a synergy effect for its participants. There is also a group of resort areas in which, in our opinion, protocluster communities have been formed. Protoclusters are formed around the climatic resort areas of Karkaralinsk, Borovoy and Altai, the first protocluster group. These protoclusters are developing at a similar pace and have significant economic potential. With the development of internal ties and the involvement of the local community in the creation of a diverse tourist product, they can form full-fledged cluster models. We also see significant potential in two regional destinations-on the shores of the Caspian Sea and in the historical and religious center of Turkestan. Both of these destinations have unique competitive advantages that can become a base for the development of a full-fledged tourist cluster. All the aforementioned facts provide evidence that the managerial approaches applied by 
the government and the business in the touristic area have not provided convincing and efficient results recently. Concurrently, according to Porter's expert opinion, the realization of the cluster initiative was not sufficient due to the lack of high-quality information-analytical tools for analysis [11].

It seems that the problem of tourism development in the country has proved to be much more complicated and, therefore, conceptually unresolved. Therefore, life itself requires the search for new scientific approaches.

The purpose of this study is to determine the conditions for the formation of tourist clusters based on their localization with the participation of local cultural and business communities.

The author's hypothesis suggests that combining state support with the involvement of local businesses can give a synergistic effect, increasing the growth of the flow of tourists in the country. To confirm this thesis were held:

Analysis of modern scientific literature on approaches to the development of national tourism;

Statistical analysis of open data on the development of the tourism industry in the Republic of Kazakhstan;

- $\quad$ a survey of experts on foresight methodology using the Delphi method.

The scientific novelty in many ways lies in the fact that the combination of the development of local business based on the cultural heritage of past centuries and modern models of digitalization of tourist activities can lead to many positive phenomena. In particular, to ensure the growth of tourist traffic, the emergence of new professions, etc., along with the cluster approach under the state management of the development of tourist destinations it is necessary to use the concept of the "experience economy". The formation of tourist clusters in the country should be based on the development and support of the participation of local communities and the creation of tourist products based on the economy of impressions. We have used foresight research data from 2020 for determining the perspectives for tourism development in Kazakhstan, in which one of the co-authors directly has participated. In the objective of forming the atlas of future professions [12] in the county it was conducted so called "Research of the map of future and demanded professions in the touristic industry within Republic of Kazakhstan". In the research, 103 tourism experts took part, including Kazakhstani touristic associations, Kazakhstani hotels and restaurants association, the national resorts association, the national industrial trade unions of employees from the culture, sports, tourism, and information centers. Furthermore, representatives from the certified center of hospitality sector and top companies from the touristic and educational sectors took a part as well.

The study methodology assumed conducting a survey, in the course of which, the experts pointed out that tourism development across Kazakhstan is hindered by the underdeveloped infrastructure (responses by $81 \%$ of the experts). Also, there is a deficit of qualified employees, which is a serious hurdle for the development of the touristic sector in Kazakhstan. Another significant issue is the quality of the service in the touristic sector, which was confirmed by $77 \%$ of the respondents.

\section{State of the Art: Literature Review and Statistics}

\subsection{Concept of Clusters' Development}

The cluster development model deserves attention, as its introduction into the tourism industry is associated with significant implementation practices and a large amount of theoretical research and can be vital for the entire national economy. It should be noted that local businesses are not always fully aware of the role they play in creating a local offering or the impact they have on the image of the tourist product and, in turn, on customers $[3,13]$. In addition, they do not always realize the importance of their interaction in the organization of the tourist product and, therefore, in determining the competitiveness of the destination in the market $[4,14]$. On the basis of these assumptions, it can be concluded that the interaction of local communities can contribute to the development of the tourist 
product and tourist destination, especially if this interaction is the result of controlled rather than spontaneous activities.

The cluster requires effective management as it is implemented and consolidated by cluster members who face similar external challenges that are easier to overcome through coordinated action [15]. The cluster arises because there is an institutional context that creates advantages based on territorial proximity and existing social capital. Firms in this case will be able to be more efficient, respond faster than when they are isolated, work with customers and other firms to develop new products and processes, reduce risk perception and inspire confidence.

At the same time, it is known that the competitiveness of tourist destinations "is determined by both factors specific to tourism and a much wider range of factors affecting tourism providers" [16]. Competition between tourist destinations is usually focused not on certain aspects of the tourist product (transport, environmental resources, hospitality, tourist services, etc.), but on tourist destinations as an integrated set of tourist experiences and objects $[17,18]$.

\subsection{The Concept of Experience Economy}

This concept is based on the «experience economy», which is defined as the tourism and its respective services and products providing experience to travelers. Also, tourism creates sensorial temptations for the customer when the visitor indirectly or directly interacts with company, product or purchasing environment for different reasons [19-22]. Researchers such as $[23,24]$ suggest that to meet emotionally created content of adventures and customer expectations, touristic companies could affect positively customer buying habits. Touristic companies could achieve competitive advantage by leveraging the cognitive and emotional experience that could be provided to customers. It could make their products and services more attractive with long-lasting effect $[25,26]$. Such a combination of cognitive and emotional content within the products and services triggers interaction between the rational and emotional dimensions of the products. Other studies suggest that the emotional component in the customer experience boosts the emotional connection with the customers [27].

In tourism the consumer experience is the core product and production process of touristic products. Also, the customer experience needs to be created based on principles of designing touristic impressions among the travelers. "Experience Economy" consists of several created impressions such as entertainment, education, transformation of the reality and esthetics. The tourism enables all of these dimensions to be activated in order to attract and engage the tourist by creating a customer-personalized product, which is basically the customer impression [28]. The gurus of the so-called emotional approach are considered Rais and Traut [29], who have conducted research on gnoseology, which clearly defines the term of consumer impression. Furthermore, the emotional element of marketing has been researched in a body of work by Sheth, who has put an accent on personalization of the product with the customer [30]. The role of the clients in the process of creating consumer experience was researched before by [31].

The tourism offers the consumers "impressions" as an integrated satisfaction of all needs by the prevailing synergy effect with additional values. Consumer experience in tourism is a result of emotional work of the employees in terms of meeting the tourists' demands. "The impression" creates completely new customer value as for the tourists, companies, and the government.

\subsection{The Link between Ecotourism and Experience Economy}

The strategic priority of most countries in recent years has been the concept of a transition to sustainable development-the integration of environmental security with balanced economic development. The use of the latest technologies, which not only reduce the negative impact on the environment but also improve the efficiency of natural resources, is helping to accelerate this process. 
In general, tourism is one of the most important sectors of the world economy and at the same time one of the most profitable activities in the world. Tourism accounts for about $10 \%$ of gross global product, $30 \%$ of exports of all services in the world, $7 \%$ of investments, $10 \%$ of jobs and $5 \%$ of world taxes. In terms of profitability, world tourism confidently ranks third among industries [32].

The most promising aspects in the world tourism is ecotourism [33]. WorldTourism Organization under the United Nations Specialized Agency (UNWTO) experts predict ecotourism for the most significant growth rate in the coming decades compared to other tourism destinations. According to their data, the global number of trips to protected natural areas in 2019 amounted to 8 billion visits, $80 \%$ of them visits to environmental areas. On average, the ecotourism market has been growing by about $25 \%$ in recent years.

Every year, the number of tourists who prefer to stay in environmentally friendly zones have multiplied. According to the Global Search Trends report submitted by the International Independent Institute of Agricultural Policy (MNIAP), the number of requests related to eco-tourism and outdoor recreation in search engines tends to increase. Thus, the number of requests for "fishing on the lake" increased by 2.7 times, "travel to nature" 2.5 times, "geological tour" 1.9 times, "agrotourism" by 57\%, "travel with zero waste" by $48 \%$, and "environmentally friendly cities" by $38 \%$ [34].

Under the influence of the pandemic caused by coronavirus disease 2019 (COVID-19), industry experts note that the tourism sector will never be the same, social distancing will increase, travelers will pay more attention to safe recreation measures. Since tourism is associated with the provision of services to the population, with their movement around the world, it is this area that has been among the most affected by the declaration of a pandemic worldwide and the closure of borders between countries.

\subsection{Kazakhstan Eco-, Ethno- and Agrotourism and Experience Economy}

Tourism represents one of the most profitable and most dynamic developing industries in the world economy. In Kazakhstan, the touristic industry is considered as an industry with high priority in the national economy, which is catalyzer for the socio-economic development of the country. Tourism has an imminent and multiple effect on the infrastructure, transport, trade and the entertainment in a country.

Tourism destinations of Kazakhstan are not yet widely represented in the world tourism market but having unique natural resources and cultural and historical heritage sites, the country has the potential to occupy a worthy place in the world tourism.

Out of the 1121 UNESCO World Heritage Sites, five are in Kazakhstan, three of which are cultural heritage sites and two are natural heritage sites [35].

Cultural objects:

- $\quad$ Khoja Ahmed Yasawi mausoleum;

- Petroglyphs in the archaeological landscape of Tamgala;

- $\quad$ Silk Roads: Chang'an-Tianshan Corridor Network Natural objects (cross-border property);

- $\quad$ Saryarka-Steppe and Lakes of Northern Kazakhstan;

- West Tian Shan.

Tourism in Kazakhstan is not yet a highly profitable industry and is not an attractive investment destination. In the country's GDP, tourism services are only $1.8 \%$. Despite this, there are already positive changes in the tourism sector. In the last year alone, the volume of services provided by various tourism companies has increased by $17 \%$, the flow of visitors to inbound tourism has increased by $14 \%$, and the expenditure of foreign nationals on trips to Kazakhstan has increased by $5.6 \%$.

According to the World Economic Forum, in 2019 Kazakhstan ranked 80th out of 140 countries in the world index of competitiveness in tourism, improving the indicator by the 1st position compared to 2017 [36].

Priority destinations, the active development of which is enshrined in the State Program for the Development of the Tourism Industry of Kazakhstan for 2019-2025 [32], are: 
- The mountain cluster of the Almaty region with the potential of 2.5 million tourists per year;

- Lake Alakol with the potential of 2 million tourists a year;

- The Juchin-Borov resort area has the potential of 2 million tourists per year;

- The development of historical and cultural tourism in Turkestan with the potential of 1.5 million tourists per year;

- The development of Meetings, Incentives, Conferences and Exhibitions (MICE) tourism in Nur Sultan city with the potential of 1 million tourists per year;

- The development of Mangystau beach tourism with the potential of 750,000 tourists per year;

- Bayanaul resort area, with the potential of 450,000 tourists per year;

- Imantau-Shalkar resort area, with the potential of 400,000 tourists per year;

- Lake Balkhash, with the potential of 400,000 tourists per year;

- The development of the tourist zone "Baikonur" as an entertaining tourist hub, with the potential of 250 to 500,000 tourists per year.

By the end of 2018, the industry employed about 44,600 people:

- In the activities of travel agencies and operators, booking and related activities: 7400 people with an average monthly salary of 95,000 tenge;

- 29,200 people with an average monthly salary of 124,000 tenge in the provision of temporary accommodation services;

- In spa organizations, 8000 people with an average monthly salary of 91,000 tenge.

In 2019, 6.3 million visitors were served by hotels and other accommodations, and 1.2 million people were served by resort areas. By the end of 2019, the number of accommodation units reached 3592, of which 2095 units were hotels, and 1497 units were other places for accommodation; 250 hotels have a star category, the largest share is 3 - and 4-star hotels. Hotels with 5 stars account for $12 \%$ of hotel facilities, and 1-star hotels account for $5 \%$.

In the process of providing services, these companies face a number of internal and external problems that have a direct impact on the efficiency of their activities, and without a timely and competent solution of which, the further development of the industry will be very difficult. According to industry experts, two groups of problems have the greatest impact on the development of the tourism sector: infrastructure, quality of service and personnel.

The development of tourist infrastructure at the end of 2019 was characterized by the fact that there were 2095 hotels, 84 holiday homes, 80 resorts, 52 tourist camps, 42 campsites and motels in Kazakhstan.

The cultural and entertainment program offers tourists 250 museums, 154 recreation parks, 101 cinemas, 65 theaters, 36 concert organizations, 18 zoos and 3 circuses. At the same time, there are about 3 museums, 2 parks, 1 cinema, and theaters, zoos and circuses less than one.

Experts note that it is very important to deal with the development of tourist destinations, transport and cultural infrastructure, environmental protection, expanding the range of services provided and attracting customers.

Transport infrastructure has the following level of development: $35.3 \mathrm{~km}$ of roads account for $1000 \mathrm{~km}^{2}$ of the country's territory, of which $30.5 \mathrm{~km}$ have a solid coverage. And the objects of rural or mountain tourism in most are not provided with high-quality access roads.

According to experts, the poor quality of the service provided by tourist services is the second most important problem in the industry.

Also at the moment, according to experts, the tourism industry feels an acute shortage in qualified personnel.

Kazakhstan adopted in 2013 a new concept to create impressions as the core of the product of the tourism industry. The new message of discover and explore offers tourists unique consumer value: "Choose Kazakhstan, because only here you will find a variety 
of ethnicities, religions, culture and languages, cuisine, nature and climate, historical and sacred places and get a unique impression (experience)". The new product is based on the development of the national model of hospitality. According to the national company "Kazakh Tourism", of the tourists visiting the country $65.6 \%$ noted a special hospitable atmosphere, $81 \%$ an interesting history and original culture, $66 \%$ adventure, and $53 \%$ the mountain tourism.

To gain a successful customer experience of a tourist in Kazakhstan, you need to use a recognizable cultural code. The cultural code is the key to understanding the unique cultural characteristics that people inherited from their ancestors; some form of information that identifies the culture. In this model of development, the emphasis is on involving the local community in the formation of a special cultural event environment, in which residents and guests become participants in the joint creation of a unique consumer experience.

The new concept of an experience economy at the moment corresponds to a number of destinations with a clear idea:

- Almaty and Almaty region-a metropolis with its special atmosphere and urban life and region-with its diverse nature from sandy deserts to snowy peaks;

- Nur Sultan and Burabai is a young capital with modern architecture and a resort area with beautiful natural scenery;

- Shymkent and Turkestan-incredible hospitality, rich gastronomic experience, opportunity to plunge into the past and learn the history of the Great Silk Road;

- The Mangistau region is the Caspian coast and the Martian landscapes of the Ustyurt Plateau;

- Eastern Kazakhstan is the incredible nature of the Altai Mountains, the cradle of Turkic civilization, with ancient mounds and sacred places.

A database of 125 investment projects worth 1694.5 billion, with the creation of 40,273 jobs, has been formed in the country. The most developed mountain cluster is the Almaty region, which has the potential to receive 2.5 million tourists a year. The development of historical and cultural tourism in the destination of Turkestan has the potential of 1.5 million tourists a year. The development of beach tourism in Mangystau has the potential of 750,000 tourists per year [32].

In order to realize the possible potential, it is necessary to carry out targeted work not only to invest in tourism facilities and remove administrative barriers, but also to develop the human potential of the local community.

\section{Materials and Methods}

\subsection{Technical Approaches and Methodology}

The methodological work is based on recommendations prepared by the International Labour Organization (ILO). The methodology of the study is based on the Technological Foresight of Competence (STF), developed by the International Labour Organization, the Agency for Strategic Initiatives of the Russian Federation and the Skolkovo Moscow School of Management (RF) and adapted to the realities, standards and requirements of the Kazakhstan economy.

In June 2010, at the G20 Leaders' Summit in Toronto, the International Organization presented the Group's Training Strategy, "Skilled workforce is the foundation of intensive, sustainable and balanced growth". [37]. In 2012, in Seoul, G20 leaders reaffirmed their willingness to support developing countries in implementing national competency strategies. The main objective of the G20 Training Strategy is to predict competencies in line with future market conditions, taking into account international changes such as innovation and technological progress.

As part of the G20 Strategy for Training Project, the ILO and the Moscow School of Management of Skolkovo have developed a method of technological foresight competence (STF). In 2013, the Skolkovo Moscow School of Management and the ILO held a seminar "Applying Foresight Technologies to determine future competence needs" on the basis of which the STF methodology was formally enshrined in 2016. 
Group work on the process of STF is a certain format of communication, combining approaches to predicting competencies and a methodology of technological foresight, allowing future needs in competences to be determined in the context of technological changes and innovations.

An important feature of STF, like all other foresight methods, is the fact that in addition to the implementation of predictive tasks, it allows participants to agree on actions in the context of the desired future. Work on the STF methodology involves the support of the discussion by an experienced moderator, a method specialist who helps the group to conduct the discussion in a certain methodology, to go through all the necessary steps to get the desired result and is responsible for the group dynamics of the participants. Also in the group is a collector, whose tasks are to retain the overall scope of the discussion, fix the primary material (the log of the session), primary processing and analysis of the results of the discussion, and create the initial result of the session (assembly).

The foresight session itself involves a number of steps in the discussion, each of which is critical for the final result, in particular the definition of trends affecting the touristic industry.

\subsection{Development of Questionnaire for Interviewing the Selected Experts}

For interviewing the experts, the questionnaire method was used, which refers to quantitative methods of marketing research and was carried out through a structured (formalized) interview.

A structured interview is a formal survey procedure characterized by a standard interview plan, namely, the approved wording of the questions (mostly closed) and the set of answers to them, as well as a fixed sequence of questions.

At the same time, the conduct of such interviews was strictly regulated, and the system of polls could not deviate from the given sequence of questions, answers to them, change the wording, ask additional questions.

In order to conduct an expert survey by the method of a questionnaire, a research toolkit (a questionnaire) was developed with open and closed questions, with the help of information collected in the field of the subject being studied.

The approved questionnaire, proposed for the experts' filling, contained 43 questions that were grouped into 5 thematic sections: Respondent data (6); Assessing the current state of the industry (7); Assessing factors that affect the future of the industry (7); Trends and technologies of the future of tourism (7); Assessing the level of skills of specialists; Competences of the Future (16).

The survey was conducted on the basis of the electronic survey platform GoogleForms. The questionnaire was presented to experts in 3 languages: Kazakh, Russian and English (survey across the experts and foresight sessions was conducted by «Research Group DAMU RG» in the framework of consulting services from the Atlas of New Professions and determining of future competences in the transport-logistical, touristic and information technology (IT) industries).

\subsection{Selection of the Experts for the Applied Questionnaire}

The selection of industry experts was based on the involvement of representatives of various stakeholders in the industry. Consultations with industry associations were held and their recommendations on the selection of industry experts for surveys were taken into account. Before the start of field work (polls), joint work was carried out with industry associations and relevant government bodies in terms of attracting industry experts to the survey method. The Kazakhstan Tourism Association received a list of key companies and experts recommended for recruitment and the questionnaire.

Before the launch of the questionnaire survey, a video conference was held with experts of the tourism industry, where the goals and objectives of the project were presented, and participants of the video conference received a link to the questionnaire "Exploring the image of the future of tourism in Kazakhstan and the sought-after competencies in the 
industry". The link to the questionnaire was also sent through associations, leading experts and industry groups in messengers.

\subsection{Conducting the Survey among the Experts}

The survey "Research on the future of tourism in Kazakhstan and the sought-after competencies in the industry" was conducted among 103 industry experts from the Kazakhstan Tourism Association (KTA), the Kazakhstan Hotel and Restaurant Association, the National Resort Association of the Republic of Kazakhstan, the Kazakhstan Branch Trade Union of Culture, Sports, Tourism and Information Workers, the Certification Center of the hospitality industry at the KTA and Kazakhstan Association of Hotels and Restaurants (KAGIR).

Seven categories of specialists took part in the survey. The experts interviewed were experienced representatives of the industry: $73 \%$ had more than 5 years of experience in the industry, which is sufficient to understand the current problems and prospects for the development of the industry. Of the 103 experts surveyed, the majority were: shareholders/owners/owners (38\%), senior management of the organization $(26 \%)$ and top management $(26 \%)$. In general, the structure of the experts' positions ensures the industry validity of the survey, and the large representation of the first three categories allows us to determine the vision of the future of the tourism industry not only from the point of view of the direct provision of services, but also from the point of view of science and educational process.

The results of the questionnaire were the basis for the preparation of the foresight session and the content part of the Atlas of New Professions and Competences in the Tourism Industry [38].

\subsection{Conducting of Specialized Foresight Sessions with Experts}

The foresight, being an active method of forecasting, uses a set of cognitive and logicalprobability methods based on collective expert evaluation. In-depth interviews are one such method.

The project conducted 14 in-depth interviews with tourism experts, where they shared their vision of the industry's development trends within global and industry trends. Experts also identified the technologies that will have the greatest impact on the development of the industry in the next 10-15 years, and the professions that, in their opinion, will appear in the labor market, will be transformed, or will disappear.

On 19-21 August 2020, a foresight session was held as part of the development of the Atlas of New Professions and Competencies in the Tourism Industry, which was attended by a total of 135 industry experts over a three-day period. BTS is an education provider, which acted as a methodological partner of this event and the project of the professions and competencies in 9 industries.

The work in the industry foresight session was based on the management of discussions by experienced moderators, who held the group's discussion in the direction of the future, preventing us from discussing the current problems of the industry. All the necessary steps were taken to achieve the desired result-the image of the future, new, transforming and disappearing professions. At the same time, the teams worked with assemblers whose tasks included retaining the overall discussion framework, fixing the primary material (session log), initial processing and analysis of the results of the discussion, and creating a suspended session result (assembly).

Representatives included those of the ISS Tourism Industry Committee of the Republic of Kazakhstan, Kazakhstan Tourism Association, regional tourist offices and associations, educational institutions, as well as leading companies of the sector: Open Travel Advisory LLT, "Touristik" "Lamjor", "Mouzenidis Travel Astana and "Golden Caravan" LLO, "Tourism Center".

The participants of the foresight sessions were divided into 3 thematic groups: Prospects for the development of travel agencies; Prospects for the development of tourist destina- 
tions and tour operators; Prospects for the development of activities to provide temporary accommodation, nutrition and other related services.

Over the course of three days, experts determined under the influence of what trends and technologies will develop in Kazakhstan tourism, jointly designing the image of the future of the industry and identifying new sought-after professions for the next 10-15 years. The foresight session was based on a consistent discussion of industry issues according to the following program:

On the first day, experts discussed trends and subjects that will have the greatest impact on the development of the industry, as well as the risks and opportunities associated with these trends.

The second day of the foresight session was given over to discussing technologies that will be introduced in the tourism industry in the next $10-15$ years and have a significant impact on the development of the industry. They also tried to imagine what Kazakhstan's tourism will be like in 2035 .

The result of the third day of work of industry experts was a list of new professions that will appear in the next 10-15 years in the tourism industry of Kazakhstan. Professions have been generated, which will soon be unclaimed in the labor market and will disappear, as well as those that under the influence of innovative technologies will be transformed or supplemented by new competencies.

\section{Results}

\subsection{Brief Conclusions and Recommendations from the Experts Based on the Conducted Survey}

The key trends that will have the greatest impact on the development of the domestic tourism sector in the next 10-15 years, among others, are the growing popularity of eco-ethno and agrotourism in Kazakhstan; and an increase in the number of the most personalized offers of the tour product.

\subsection{Future Areas in Tourism through the Lenses of the Experts}

According to Shaikenova R.R., director of the Kazakhstan Tourism Association, the industry has undergone quite serious changes over the past 5-10 years: "This period of rebooting we called 'return to its roots' because nature must be served in conjunction with culture, with history. Our nomadic culture and Turkic civilization are very interesting for tourists" [39].

Rei I.Y., chairman of the corporate fund "Touristic zhamjor", and owner and founder of the tourist company "Sayat", noted that the attractions themselves cannot be a readymade tourist product: "Tourism is a set of certain actions that create a tourist product by the state and the tour community".

Weimer A.F., director of the Taraz Tourist Center, Golden Caravan, chairman of the Association of Inland and Inbound Tourism, and certified international tour guide, emphasized that today the tourism business needs to focus attention and make every effort to start developing domestic tourism in the country.

Tickenov E.A., director of Inside Travel LLO, said that considering trends, it is worth dividing them into global long-term and regional medium-term. From the international trends of tourism in recent years and for the next decade the trend aims at sustainable development, ecology and preservation of natural systems and communities, their authenticity.

\subsection{Forecast for Development of the Touristic Sector}

Industry experts, representatives of educational institutions, tried to look for 10-15 years ahead and assess how the tourism sector will develop in the near future, in what direction. Here are a few predictions.

Despite the industry's problems, $57 \%$ of industry experts assume that the tourism sector in Kazakhstan will develop successfully in the next 10-15 years. This fact is also notable for the fact that the expert survey was conducted during a difficult period for the industry, when the tourism sector was completely suspended due to the pandemic caused 
by COVID-19, when transport links with all countries were interrupted and tourists had to give up pre-purchased tours.

Experts' opinions when answering the question whether they are ready for the upcoming changes shared equally, 50\% of experts believed that already companies in the industry are ready for the upcoming changes, and 19\% of them were unequivocally sure of it. The other half of experts doubted the industry's readiness for change, and $7 \%$ of them believed that the tourism business is definitely not ready for it.

Industry experts suggested that the greatest technological breakthroughs in the next 10-15 years can be expected in the following areas of tourism activity:

- Conferences and trade exhibitions (76\%);

- In the development of tourist destinations (71\%);

- In the marketing promotion of tourist destinations (63\%).

Tourist destinations are the most important element of the tourist business. Believing that there will be a qualitative technological breakthrough in the development of tourist destinations, experts first of all meant that destinations will gradually turn into "smart" destinations, for example, as a special case of a "smart" city, affecting aspects of energy conservation and sustainable development, as well as improving the comfort and safety of tourists.

Drivers of the development of the industry in the future will be increasing demand for domestic tourism services, holding sports competitions in the country, political and economic events of the world scale.

Industry experts formed a ranking of potential opportunities that they believe are more likely to be available in the next 10 to 15 years. In their opinion, the development of the tourist sphere will be facilitated by: an increase in demand for domestic tourism services (as $60 \%$ of experts believe); holding various international sports (47\%), political and economic (45\%) in the country; world-wide events; and effective support of companies implementing the latest technologies by the state $(40 \%)$.

Analyzing the experts' answers, it is immediately striking that, despite the difficult situation in the tourism sector at that time, experts are optimistic about their future, and hence the future of their business. Only $10 \%$ of experts indicated that they felt uncertain about their future.

According to the assessment of $90 \%$ of experts of the tourism industry, the formed image of the future, primarily has the potential for comprehensive personal development and limitless possibilities (according to 33\% of experts) and gives a sense of confidence in the future $(29 \%)$.

\subsection{Trends and Technologies, Forming Future Touristic Industry in Kazakhstan}

The transformation of the tourism sector is influenced by a large number of trends. Industry experts have identified a number of global and industry trends that can be grouped into six leading pillars as follows [40]:

- Increasing the adoption of robots and smart systems;

- Expanding the applications of digitalization and big data;

- Improving the efficiency of the industry's resource management;

- Improving service environmental requirements;

- Changing the queries and requirements of the $\mathrm{Y}$ and $\mathrm{Y}$ generation;

- Changing consumer preferences;

- Let's take a closer look at one of these trends.

\subsection{Demand for More Ecological Tourism}

Improving the requirements for environmentally friendly services in the next 10-15 years, according to industry experts, will provide an equally strong (44\%) and average (42\%) impact on the development of tourism in Kazakhstan. 
According to the experts, tourism generates $5 \%$ of global $\mathrm{CO}_{2}$ emissions, $40 \%$ of which are caused by air travel, $20 \%$ by hotels and other temporary accommodation, and another $40 \%$ by other modes of transport and leisure services.

Ecotourism and nature tours are popular destinations both all over the world and in Kazakhstan.

Modern travelers are eco-friendlier than ever. They prefer to walk than use a car, use only natural products, and take care of the environment. The main difference between eco-friendly hotels and traditional ones is that they are located where guests are provided with outdoor recreation, natural products are offered, and only environmentally friendly materials are used in the decoration of the rooms.

In the world tourism industry there are such hotels, where it is not possible to use cellular communication, and sometimes electricity, where water is heated by sunlight and personal hygiene products are used that do not harm the environment.

Kyzylarai is a popular place to visit for ecotourists in Kazakhstan. Tourists, if desired, can settle in a Kazakh yurt and get acquainted with the life of the local population.

There is a lot of interest from tourists in Charyn Canyon, located $200 \mathrm{~km}$ from Almaty. It is a unique place with singing sands and quaint castle-shaped cliffs, often compared to the Grand Canyon in Arizona.

Hunting with birds of prey today reaches a leading position among tourist products. Tourists from abroad specially come to the country to learn this type of hunting.

If earlier travelers tried to stay within the resort, to consume familiar food, to communicate mainly with their compatriots, modern travelers now strive to communicate with people, cultures and landscapes of the countries they visit.

Local food is a key feature of many trips, people tend to try something new. A cultural experience is the culmination of many travels, and modern travelers strive to witness the traditions of the people inhabiting a territory, as well as to take part in them.

The development of tourism services leads to the active involvement of women. Figure 1 shows the proportion of women employed in the provision of tourism services in the resort areas of Kazakhstan. It is obvious that in the majority (67\%) of the main workers in the resort areas are women. In a third of destinations, however, women accounted for $70 \%$ or more of the workforce. Women's employment in tourism services is an important factor for the development of the local community. However, women were still employed as employees in the tourism sector, while the development of tourism provided an opportunity to develop women's entrepreneurship.

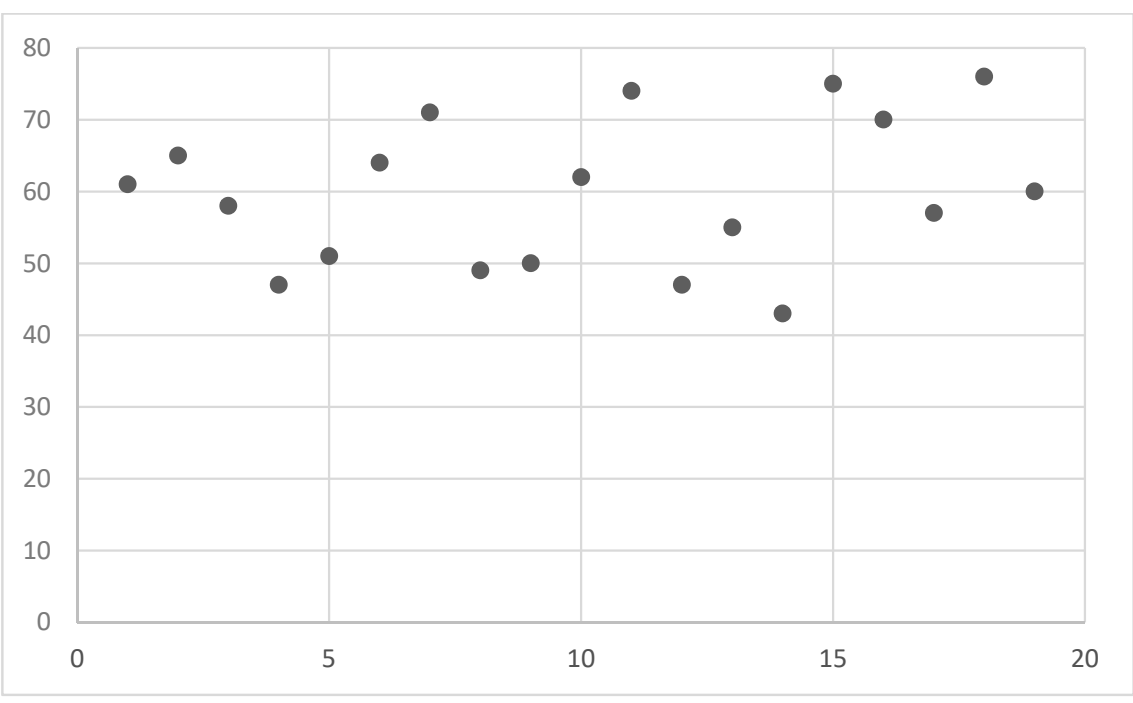

Figure 1. Ratio of women to the total number of employed in tourism in Kazakhstan, \%. Source: developed by the authors. 


\section{Discussions}

\subsection{Managerial Implications}

Our research has shown that the orientation exclusively to government programs does not give the planned result in such an emotional sphere of consumption as tourism and, therefore, does not lead to a steady increase in interest in tourism in the country. The involvement of local communities in the business is a significant and even decisive factor. Cooper and Hall [41] note the inability of governments to continue to coordinate and control activities related to hospitality and tourism. At the heart of this transformation is the changing role of government agencies. Today, direct government support is being replaced by cooperation with private sector enterprises. The role of the state is to encourage and steer the development of community-based networks and partnerships.

Tiberghien [42] notes the importance not only of "environmental aspects (flora and fauna) but also of cultural (traditional games, crafts and cooking traditions) in decorating visitors' experiences" as well as the need to create "tourist experiences where members of the host community present their daily lives and a "nomadic sense of hospitality" without creating an artistically far-fetched tourist destination for their guests". The search for authenticity sought by tourists coming to Kazakhstan and, more specifically, access to the truly semi-nomadic lifestyle of the local population becomes possible for a small number of visitors who are culturally familiar with some aspects of traditional nomadic culture.

The global pandemic and the decisions of politicians that followed put almost the entire world tourism market on pause. The losses of the tourism sector in Kazakhstan due to the coronavirus pandemic and subsequent restrictive measures reached $100 \%$. However, this means that competition will be even stronger after its completion [4]. Kazakhstan will have to form a correct and clear positioning of the country; and to make the country attractive for travel in order to escape from associations of an insecure and little-known country, so that every guest, hungry for adventure and travel, can access the homeland of true nomads.

\subsection{Practical/Social Implications for Marketers}

Once humanity has addressed the problems caused by the COVID-19 pandemic, the challenge of improving the competitiveness of national tourism will come to the fore. Future trends in tourism suggest that travelers will be concerned not just about staying in a particular place-it is in the context of developed transport systems ceased to be a problem in the 21st century, but a thirst for participation and learning in the place they visit. Tourism has become an integral part of the way of life of modern humans and, consequently, global industry, whose producers and consumers are scattered all over the world.

In this context, the public administration of tourism development should be based on the support of local cultural and business projects that can attract tourists with the opportunity to participate in the life of nomads. Kazakhstani tourism organizations need local programs to test the possibility of forming regional and local clusters, as well as to future evaluate the efforts of the members of the cluster. Local communities are natural partners who have already gained some experience in developing a local tourist product and improving the quality of the offer.

According to $[43,44]$, an important aspect of the consumption of experience is the environment in which it is delivered. The environment encourages the consumer to become a participant in consumption by joining the event. In their study of hotel services, [45] noted that the usefulness for consumers of intangible services depends on their preferences, giving experience, as well as the degree of their interaction with attributes corresponding to services. These authors, as well as others [46] claim that buyers consume an experience when they interact with the physical environment and people, and hence the atmosphere and environment, forming an experience for consumption. In this way, it is possible to form an experience for consumption in different settings, when travelers interact and become involved in the process of creation and consumption. 
Therefore, it is so important to really assess and understand at what stage of development today the tourism industry has reached, in what direction it is moving, what plans is being made for the future? This is what we, with the help of experts of the tourism industry, tried to understand.

As a result of the systematization of a large amount of information received during the foresight sessions, backed by in-depth interviews with leading industry experts and a survey of experts, a vision of the current state of the tourism sector, as well as the prospects for its development for the next 10-15 years, has been formed.

According to industry experts, the tourism industry in Kazakhstan is going through difficult times and there is a lack of development of tourism infrastructure, which has a significant impact on the competitiveness of tourist destinations and the volume of tourist flows, and therefore there is a lag of domestic tourism in the level of service provided.

Although Kazakhstan's tourist destinations are not yet widely represented in the global tourism market, but with unique natural resources and cultural and historical heritage sites, the country has great potential to occupy a worthy place in world tourism.

\section{Conclusions}

\subsection{Conclusions}

According to experts who took part in the study, eco-ethno- and agrotourism will be the main ways of tourism development in Kazakhstan. The following areas also look promising:

- Significant attention will be paid to the development of tourist and recreational zones and the promotion of tourist destinations in the domestic market and abroad.

- The main principle of tourism development will be the transition to a green economy and the achievement of sustainable development goals. Tourism companies, local people and tourists together take care of the environment, care about the preservation of national culture, but also focus on touristic destinations capabilities [47].

- There will be a significant increase in the popularity of domestic tourism. Kazakhstan will become more recognizable in the global tourism industry, which will contribute to a gradual increase in the number of visitors to inbound tourism.

- Tourism itself will be represented by two segments. The first segment, mass and accessible for almost every person. The second, elite personalized tour products, expensive in value and associated with the participation of a personal manager at all stages of service.

- Tourism such as ecotourism, ethnotourism and agrotourism will be most prevalent. Also, a lot of attention will be paid to the development of space tourism (in the form of a visit to the Baikonur launch site).

Based on the importance of eco- ethno- and agrotourism for Kazakhstan, the need to conserve natural tourism resources and based on the opinions of experts, the authors believe that more. One of the important findings of this study is the need for cooperation between the state, local communities and tour operators in the planning of tourism of various Kazakhstani historical and cultural sites to ensure the further development of tourism in rural areas of Kazakhstan. By helping to determine how local communities can meet visitor expectations and what types of tourism can be offered in rural areas, local communities play an important role in supporting alternative tourism projects that involve a high level of community-based relationships. By helping to develop a network of holiday homes in rural communities and, for example, to support the production of traditional craft souvenirs, local communities are involved in authenticating and developing tours that can meet visitors' expectations of authenticity when traveling around the country.

\subsection{Limitations and Future Research}

The study has several limitations. Thus, the basis of the empirical material are the data obtained through the methodology of technological foresight competences. The methodology 
identified and analysed expert opinions and thus allowed us not only to determine the direction of future development, but also to form a network of interested stakeholders.

However, in the first stage of the study, consumers of tourist services were excluded from the study. The authors intend to continue this study with a qualitative study based on a large-scale survey of consumers of tourist services in order to study the perception and satisfaction of interested tourists with a new tourist product in Kazakhstan. This approach aims to identify gaps and further overcome the expectations of tourists, to give a more in-depth overview of the mechanism of obtaining a tourist experience, and to formulate a set of recommendations for the producers of tourist services of local communities and authorities. Thus, Kazakhstan will be able to develop a tourism brand recognized at the international level.

Author Contributions: Conceptualization, N.K. and Y.P.; methodology, N.K.; software, E.V.; validation, N.K., Y.P. and I.D.; formal analysis, N.K.; investigation, E.V.; resources, E.V.; data curation, N.K.; writing—original draft preparation, I.D.; writing—review and editing, E.V.; visualization, Y.Z.; supervision, Y.Z.; project administration, N.K.; funding acquisition, N.K. All authors have read and agreed to the published version of the manuscript.

Funding: This research received no external funding.

Institutional Review Board Statement: Not applicable.

Informed Consent Statement: Not applicable.

Conflicts of Interest: The authors declare no conflict of interest.

\section{References}

1. Dosaliev, U.K.; Urazbaeva, G.Z.H.; Abishova, A.U.; Utemisova, G.T. Razvitie Industrii Gostepriimstva Kak Odnogo Iz Prioritetnyh Napravlenij Razvitiya Turizma v Respublike Kazahstan. J. Cent. Asia Econ. 2017, 1, 91-100.

2. Petrenko, E.S.; Dauletova, A.M.; Mazhitova, S.K.; SHabaltina, L.V. Analiz Mer Gosudarstvennoj Podderzhki Po Razvitiyu Turizma v Respublike Kazahstan. J. Int. Econ. Aff. 2019, 9, 2677-2692.

3. Yakovchuk, A.A. Ocenka Effektivnosti Regional'noj Politiki v Sfere Turizma. J. Int. Econ. Aff. 2019, 9, 3103-3114.

4. Dagman, S. Konceptual'nye Podhody k Ustojchivomu Turizmu Na Osnove Ispol'zovaniya Integral'nyh Metodov Marketinga. J. Int. Econ. Aff. 2019, 9, 3115-3128.

5. Kuznecova, O.P.; Kos'min, A.D.; Kuz'menko, A.A.; Kuznecov, V.V.; Kuznecova, S.V.; Samohvalova, O.M. Turizm Kak Drajver Social'no-Ekonomicheskogo i Sociokul'turnogo Razvitiya Strany. J. Int. Econ. Aff. 2019, 9, 2165-2178.

6. Porter, M.E. The Competitive Advantage of Nations; Free Press: New York, NY, USA, 1990.

7. Porter, M.E. Clusters and the New Econormics of Competition; Harvard Business School Press: Boston, MA, USA, 1998.

8. Torre, A.; Rallet, A. Proximity and Localization. Reg. Stud. 2005, 39, 47-59. [CrossRef]

9. Cooke, P. Regional Innovation Systems, Clusters, and the Knowledge Economy. Ind. Corp. Chang. 2001, 10, 945-974. [CrossRef]

10. Jackson, J.; Murphy, P. Tourism Destinations as Clusters: Analytical Experiences from the New World. Tour. Hosp. Res. 2002, 4, 36-52. [CrossRef]

11. Kriticheski, M.P. Otsenil Rabotu v Kazakhstane Proyekta Klasternaya Initsiativa. Available online: https://www.zakon.kz/1174 63-professor-majjkl-porter-kriticheski.html (accessed on 14 February 2021).

12. Atlas of New Professions and Competencies in the Republic of Kazakhstan. Available online: https://www.enbek.kz/atlas/en (accessed on 14 February 2021).

13. Rispoli, M.; Tamma, M. Goods and Services, That Is, Products. Sinergie Ital. J. Manag. 2016, 100, 203-219. [CrossRef]

14. Minghetti, V. From Destination to Destination Marketing and Management: Designing and Repositioning Tourism Products. Int. J. Tour. Res. 2001, 3, 255-257. [CrossRef]

15. Doloreux, D.; Shearmur, R. Maritime Clusters in Diverse Regional Contexts: The Case of Canada. Mar. Policy 2009, 33, 520-527. [CrossRef]

16. Enright, M.J.; Newton, J. Determinants of Tourism Destination Competitiveness in Asia Pacific: Comprehensiveness and Universality. J. Travel Res. 2005, 43, 339-350. [CrossRef]

17. Crouch, G.I.; Ritchie, J.R.B. Destination Competitiveness. In International Handbook on the Economics of Tourism; Edward Elgar Publishing: Cheltenham, UK, 2013.

18. Buhalis, D. Marketing the Competitive Destination of the Future. Tour. Manag. 2000, 21, 97-116. [CrossRef]

19. Patrício, L.; Fisk, R.P.; E Cunha, J.F.; Constantine, L. Multilevel Service Design: From Customer Value Constellation to Service Experience Blueprinting. J. Serv. Res. 2011, 14, 180-200. [CrossRef]

20. McGinnis, L.P.; Gentry, J.W.; Gao, T. Antecedents to Consumer Perceptions of Sacredness in Extended Service Experiences. J. Serv. Res. 2012, 15, 476-488. [CrossRef] 
21. Daugstad, K. Negotiating Landscape in Rural Tourism. Ann. Tour. Res. 2008, 35, 402-426. [CrossRef]

22. Adhikari, A.; Rao, A.K. Individual Preference and Bargaining Behavior in Families' Buying Decisions of Restaurant Service. Cornell Hosp. Q. 2012, 54, 248-261. [CrossRef]

23. Schmitt, B. Experiential Marketing: How to Get Customers to Sense, Feel, Think, Act, and Relate to Your Company and Brands; Free Press: New York, NY, USA, 1999.

24. Ritchie, J.R.; Hudson, S. Understanding and Meeting the Challenges of Consumer/Tourist Experience Research. Int. J. Tour. Res. 2009, 11, 111-126. [CrossRef]

25. Terblanche, N.S. Customer Experiences, Interactions, Relationships and Corporate Reputation: A Conceptual Approach. J. Gen. Manag. 2009, 35, 5-17. [CrossRef]

26. Ryan, C. The Tourist Experience: A New Introduction; Continuum: London, UK, 2002.

27. Cetin, G.; Bilgihan, A. Components of Cultural Tourists' Experiences in Destinations. Curr. Issues Tour. 2015, 19, 137-154. [CrossRef]

28. Pine, B.J.; Gilmore, J.H. The Experience Economy: Past, Present and Future. In Handbook on the Experience Economy; Edward Elgar Publishing: Cheltenham, UK, 2014; pp. 21-44.

29. Ries, A.; Trout, J. Positioning the Battle for Your Mind; McGraw-Hill: New York, NY, USA, 2001.

30. Gilly, M.C.; Sheth, J.N.; Newman, B.I.; Gross, B.L. Consumption Values and Market Choices: Theory and Applications. J. Mark. Res. 1992, 29, 487. [CrossRef]

31. Resnick, S.; Cassidy, K.; Fox, C. A Perspective on Relationship Quality in Drug Treatment Services Using Patient to Patient Research. Available online: https:/ / core.ac.uk/display/30639157 (accessed on 14 February 2021).

32. Ob Utverzhdenii Gosudarstvennoy Programmy Razvitiya Turistskoy Otrasli Respubliki Kazakhstan na 2019-2025 Gody. Available online: http:/ / adilet.zan.kz/rus/docs/P1900000360 (accessed on 14 February 2021).

33. World Tourism Organization. Available online: https://www.unwto.org/global-and-regional-tourism-performance (accessed on 14 February 2021).

34. Global'nyye Trendy Poiskovykh Zaprosov. Available online: http://xn--80aplem.xn--p1ai/analytics/Globalnye-trendypoiskovyh-zaprosov / (accessed on 14 February 2021).

35. United Nations Educational Scientific and Culture Organization. World Heritage Convention. World Heritage List. Available online: https:/ / whc.unesco.org/en/list/ (accessed on 14 February 2021).

36. Travel \& Tourism Competitiveness Index 2019 Edition. Available online: http://reports.weforum.org/travel-and-tourismcompetitiveness-report-2019/country-profiles / (accessed on 14 February 2021).

37. A Skilled Workforce for Strong, Sustainable and Balanced Growth: A G20 Training Strategy. Available online: https: / www.ilo. org/moscow/information-resources/publications/WCMS_345398/lang--en/index.htm (accessed on 14 February 2021).

38. Atlas of New Professions and Competencies. Available online: https://www.enbek.kz/atlas/en/industry/5 (accessed on 14 February 2021).

39. Atlas of New Professions and Competencies. Available online: https://www.enbek.kz/atlas/en/experts-opinion (accessed on 14 February 2021).

40. Saura, J.R.; Ribeiro-Soriano, D.; Palacios-Marqués, D. From user-generated data to data-driven innovation: A research agenda to understand user privacy in digital markets. Int. J. Inf. Manag. 2021, 102331. [CrossRef]

41. Cooper, C.; Hall, C.M. Contemporary Tourism Product Markets. Contemp. Tour. 2008, 25-48. [CrossRef]

42. Tiberghien, G. Managing the Planning and Development of Authentic Eco-Cultural Tourism in Kazakhstan. Tour. Plan. Dev. 2018, 16, 494-513. [CrossRef]

43. Shugan, S.M.; Xie, J. Advance Pricing of Services and Other Implications of Separating Purchase and Consumption. J. Serv. Res. 2000, 2, 227-239. [CrossRef]

44. Mossberg, L. A Marketing Approach to the Tourist Experience. Scand. J. Hosp. Tour. 2007, 7, 59-74. [CrossRef]

45. Goldberg, S.M.; Green, P.E.; Wind, Y. Conjoint Analysis of Price Premiums for Hotel Amenities. J. Bus. 1984, 57, S111. [CrossRef]

46. Ofir, C.; Raghubir, P.; Brosh, G.; Monroe, K.; Heiman, A. Memory-Based Store Price Judgments: The Role of Knowledge and Shopping Experience. J. Retail. 2008, 84, 414-423. [CrossRef]

47. Sainaghi, R.; De Carlo, M.; d'Angella, F. Development of a Tourism Destination: Exploring the Role of Destination Capabilities. J. Hosp. Tour. Res. 2018, 43, 517-543. [CrossRef] 